\title{
IMPACT OF FIIS ON INDIAN ECONOMY
}

\author{
1 Dr. Ritika Sinha
}

\begin{abstract}
Since the beginning of liberalization in 1990s, Fll flows to India have steadily grown in importance. From a near absence of Fll inflows till 1992, today such inflows represent a dominant proportion of total flows. Positive fundamentals, gradual removal of structural barriers combined with fast growing markets have made India an attractive destination for foreign institutional investors. Funds flow from Flls have crossed the record Rs 97,900 crore mark this year. The net purchase of Rs $97,955.50$ crore ( $\$ 21.42$ billion) is the higher ever investment by overseas firms in any single year in India. Today, Flls are the key drivers of the Indian equity market and rising stakes in Indian companies. But, at the same time there is unease over the volatility in foreign institutional investment flows and its impact on the different segments of the economy. The increase in the volume of foreign institutional investment (FII) inflows in recent time has led to concerns regarding the volatility of these flows, threat of capital flight, its impact on the stock markets and influence of changes in regulatory regimes.. Globally strong consensus has emerged that the achievement of more dynamic economic growth requires a greater role of the foreign capital. There was a surge in foreign capital flows into India after 1992-93, because of drastic changes in India's policies. Since then Government of India have been relaxing capital control measures and taking large number of policy decisions towards the improvement of local financial infrastructure. Because of this, foreign capital has become an integral part of the development strategy of India. The main objective of the present study is to investigate the impact of Flls on economic growth of Indian economy.
\end{abstract}

\section{Introduction}

One of the outstanding features of globalization in the financial services industry is the increased access provided to non-local investors in several major stock markets of the world. Increasingly, stock markets from emerging markets permit institutional investors to trade in their domestic markets. Indian stock market opened to Foreign Institutional Investors in 14th September 1992, initially with lot of restrictions. The regulation on them are liberalized and minimized now, since 1993 has received a considerable amount of portfolio investment from foreigners in the form if Flls investment in equities. This has become a turning point of India stock market. The government of India announced the policy of the government to permit the FII investment in India capital market. According to the SEBI Domestic market alone not able to meet the growing capital requirement of the country and financing from mutilated institution has lost primary in the emerging in the global order .Besides aimed primarily at ensuring non-debt creating capital inflows at a time of extreme balance of payment crisis. It was to tie over the balance of payment crisis in the early 1990s Portfolio flows often referred to as 'hot- money' are notoriously volatile capital flows. They have also responsible for spreading financial crisis causing contagion in international market. Evan though, the Flls have been plying a key role in the financial markets since their entry into this country. The explosive portfolio flow by FII brings with them great advantages as they are engine of growth, lowering cost of capital in many emerging market. This opening up of capital markets in emerging market countries has been perceived as beneficial by some researchers while others are concerned about possible adverse this opening up resulted in

1 Assistant Professor, Bangalore University, Bangalore 
a number of positive effects. First, the stock exchanges were forced to improve the quality of their trading and settlement procedures in accordance with the best practices of the world. Second, the information environment in India improved with the advent of major international financial institutional investors in India. On the negative side we need to consider potential destabilization as a result of the trading activity of foreign institutional investors. This is especially important in an emerging country that has embarked upon reforms to open up its market.

Recently, a new index, Instanex FII index15, has come into existence. This is similar to the Sensex and Nifty. It gives a feel of the FII pulse, and their moves in the stock markets. The Instanex FII index tracks the 15 stocks in which FII funds have been invested. These 15 stocks under the Instanex index account for 55 per cent of the market capitalization of the FII holdings. Long-term investors can track the FII investment data released by SEBI. The net FII investment data helps in understanding the mood of the Flls.

\section{Government initiatives:}

To further increase FIl participation in the Indian market, the government and SEBI have taken several measures

I The Government of India reviewed the External Commercial Borrowing (ECB) policy and increased the cumulative debt investment limit by US\$ 9 billion (from US\$ 6 billion to US\$ 15 billion) for FIl investments in corporate debt.

I No single entity (FII) shall be allocated more than US\$ 62.78 million of the government debt investment limit for allocation through bidding process.
I Allowed foreign individuals, corporate and other investors such as hedge funds to register directly as foreign institutional investors.

I An investment limit of US\$ 73.25 million in Government debt shall be allocated among the FIls/sub-accounts on a first-come first-served basis, subject to a ceiling of US\$10.46 million per registered entity.

I SEBI has FII investment limit in government securities being increased to US $\$ 5$ billion from US\$ 3.2 billion.

I Institutional investors-including Flls and their sub-accounts-have been allowed to undertake short-selling, lending and borrowing of Indian securities from February 1, 2008.

। SEBI has simplified the registration norms for Flls and sub-accounts.

I Significantly, it has allowed investment managers, advisors or institutional portfolio managers in the $\mathrm{NRI}$ category to be registered as Flls.

I In October 2008, SEBI did away with the 70:30 ratio of FII investment in equity and debt, respectively. Flls can now invest in equity and debt in any ration they seem fit.

I The Reserve Bank of India (RBI) and the Securities and Exchange Board of India (SEBI) have jointly unveiled norms enabling exchange-traded interest rate futures (IRF). Foreign portfolio investors have been allowed to trade in IRFs with capped limits.

- Flls and the non-resident Indians (NRIs) are allowed to invest in Indian Depository Receipts (IDRs), according to the operational guidelines issued by the RBI on July 22, 2009. 
Figure 1: Flls and the financial system

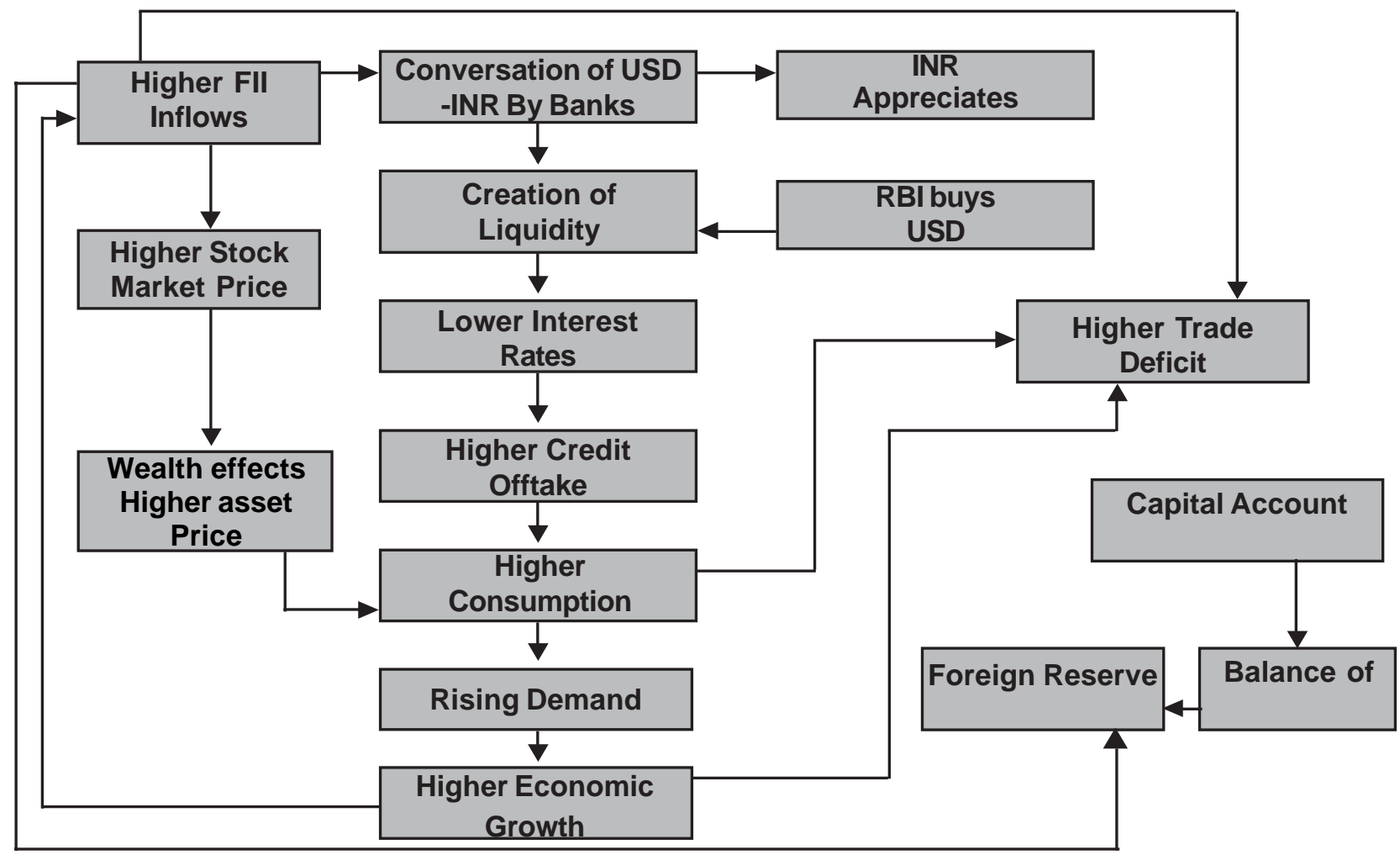

Table1: Number of Foreign Institutional Investors (FIIs)

As of March 2010, there were 1,711 Flls registered with SEBI, as against 1618 in March 2009.

\begin{tabular}{|l|l|}
\hline SEBI Registered Flls in India (Years ) & End of March \\
\hline $1992-93$ & 3 \\
\hline $1993-94$ & 156 \\
\hline $1994-95$ & 353 \\
\hline $1995-96$ & 439 \\
\hline $1996-97$ & 496 \\
\hline $1997-98$ & 450 \\
\hline $1998-99$ & 506 \\
\hline $1999-00$ & 527 \\
\hline $2000-01$ & 490 \\
\hline $2001-02$ & 502 \\
\hline $2002-03$ & 540 \\
\hline $2003-04$ & 685 \\
\hline $2004-05$ & 882 \\
\hline $2005-06$ & 997 \\
\hline $2006-07$ & 1319 \\
\hline $2007-08$ & 1618 \\
\hline $2008-09$ & 1711 \\
\hline Till Mar 2010 & \\
\hline
\end{tabular}

Source: Securities and Exchange Board of India 


\section{Indian Economy Overview :}

Economics experts and various studies conducted across the globe envisage India and China to rule the world in the 21 st century. For over a century the United States has been the largest economy in the world but major developments have taken place in the world economy since then, leading to the shift of focus from the US and the rich countries of Europe to the two Asian giants- India and China.

The rich countries of Europe have seen the greatest decline in global GDP share by 4.9 percentage points, followed by the US and Japan with a decline of about 1 percentage points each. Within Asia, the rising share of China and India has more than made up the declining global share of Japan since 1990. During the seventies and the eighties, ASEAN countries and during the eighties South Korea, along with China and India, contributed to the rising share of Asia in world GDP.

According to some experts, the share of the US in world GDP is expected to fall (from 21 per cent to 18 per cent) and that of India GDP to rise (from 6 per cent to 11 per cent in 2025), and hence the latter will emerge as the third pole in the global economy after the US and China.

Indian Economy experienced a GDP growth of 9.0 percent during 2005-06 to 9.4 percent during 2006-07. By 2025 the India's economy is projected to be about 60 per cent the size of the US economy. The transformation into a tri-polar economy will be complete by 2035 , with the Indian economy only a little smaller than the US economy but larger than that of Western Europe. By 2035, India is likely to be a larger growth driver than the six largest countries in the EU, though its impact will be a little over half that of the US. India, which is now the fourth largest economy in terms of purchasing power parity, will overtake Japan and become the third major economic power with in 10 years.

Trade liberalization, financial liberalization, tax reforms and opening up to foreign investments were some of the important steps, which helped Indian economy to gain momentum. The Economic Liberalization introduced by Manmohan Singh in 1991, then Finance Minister in the government of P V Narsimha Rao, proved to be the stepping-stone for Indian economic reform movements.
This surge in FII investment has led to the cumulative net investments by Flls into Indian equities to total US\$ 52.76 billion by the end of November 2008, since December 1993, when Flls were allowed to enter India. As of November 28, 2008, 1581 Flls and 4824 sub-accounts were registered with the Securities and Exchange Board of India (SEBI). According to the data given by the Securities and Exchange Board of India (SEBI), the FII investments in equities as on March 17, 2009 stood at US\$ 50950.20 million and in debts, equaled US\$ 6541.50 million at exchange Overseas investors have infused US\$ 816.69 million into the stock market in the first trading week of 2010 , reflecting a positive start for the year after record inflows in the last year. Foreign institutional investors (FIIs) were gross buyers of shares worth US $\$ 3.03$ billion, and sold equities valued worth US\$ 2.2 billion, resulting in a net investment of US $\$ 823.74$ million, according to the capital market regulator, Securities and Exchange Board of India (SEBI). FIls were net investors of US\$973.22 million in debt instruments in the first trading week of the year, according to data released by SEBI.

According to SEBI, Flls transferred a record US\$ 17.46 billion in domestic equities during the calendar year 2009. This FII investment in 2009 proved to be the highest ever inflow in the country in rupee terms in a single year, breaking the previous high of US\$ 14.96 billion parked by foreign fund houses in domestic equities in 2007 . Flls infused a net US\$ 1.05 billion in debt instruments during the said period.

During the October-December period in 2009-10, Flls made a net buy of shares worth US\$ 5.19 billion, according to data compiled from market regulator, the Securities and Exchange Board of India (SEBI).

In the quarter, December attracted the highest inflow of US\$ 2.2 billion, followed by October US\$ 1.95 billion and November US\$1.18 billion. Flls poured a net US\$ 1.26 billion in debt instruments during the said period.

The trend of strong FII inflows to the tune of about US\$ 6.3 billion witnessed during April-June quarter gained further during the September quarter of current fiscal with an infusion of US $\$ 7.2$ billion. 
The number of Flls who registered themselves with SEBI this year was higher by 7 per cent over 2008. Data sourced from the SEBI shows that number of registered Flls stood at 1714 and number of registered sub-accounts rose to 5,403 as of march 31, 2010.

A number of market and equity analysts indicate that a large part of FII inflows have come from long-only funds, signaling that the quality of foreign investment is good.

India has in fact, emerged the most lucrative markets for short and medium-term investments. The US is once again at the top of the list of foreign investors in the Indian stock market, as per data presented in the Lok Sabha by the Finance Ministry. According to the latest data, till mid-November 2009, US-based foreign institutional investors (FIIs) had net investments of about US\$ 4.46 billion in the Indian markets, as compared with US\$702.37 million in 2006. They are followed by the US $\$ 2.57$ billion net investments routed through Luxembourg. These two countries are further followed by France, Mauritius and the UK.

Roughly US\$ 9 million-US\$ 10 million came in the primary issuance - through qualified institutional placements (QIPs) or preferential allotment or initial public offerings (IPOs).

Private equity firms invested US $\$ 1.4$ billion over 84 deals in India during October-December quarter of 2009 , taking the annual investment numbers to US\$ 3.82 billion over 232 deals, according to a study by Venture Intelligence, a research service focused on private equity (PE) and merger and acquisition (M\&A) transactions.

Funds flow from Flls have crossed the record Rs 97,900 crore mark this year. The net purchase of Rs $97,955.50$ crore ( $\$ 21.42$ billion) is the higher ever investment by overseas firms in any single year in India.

Table 2: India's GDP rate since 2006-2009

\begin{tabular}{|l|c|}
\hline Financial year & $\begin{array}{c}\text { GDP of India at factor } \\
\text { cost (in percent) }\end{array}$ \\
\hline $2005-06$ & 9.00 \\
\hline $2006-07$ & 9.20 \\
\hline $2007-08$ & 8.70 \\
\hline $2008-09$ & 6.70 \\
\hline
\end{tabular}

Source: (RBI, Statistics on Indian Economy 2008-09)

Figure 2:India GDP growth rate :

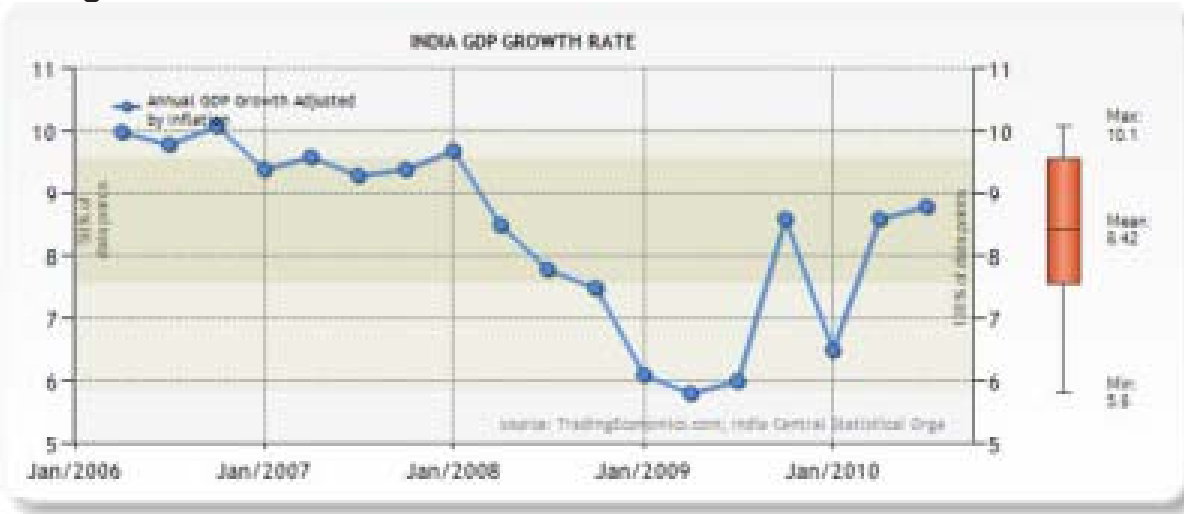

Source: India central statistical organization

$\begin{array}{lllll}\text { Year } & \text { Mar } & \text { Jun } & \text { Sep } & \text { Dec } \\ 2010 & 8.60 & 8.80 & & \\ 2009 & 5.80 & 6.00 & 8.60 & 6.50 \\ 2008 & 8.50 & 7.80 & 7.50 & 6.10\end{array}$




\section{Impact of Flls on exchange rate}

Flls also have an impact on the foreign exchange rate (Klein and Rosengrem, 1992). FII inflows make the currency of the country invested to appreciate (e.g. FII investing in India may lead to Rupee appreciating with several other currencies) and their selling and disinvestment may lead to depreciation (Mishra, 2008; Sumanjeet, 2007). The huge amount of FIl fund inflow into the country creates a lot of demand for rupee, and the RBI pumps the amount of Rupee in the market as a result of demand created by the FIl's. This situation could lead to excess liquidity (amount of excess cash floating in the market) thereby leading to Inflation, where too much money chases too few goods (perfect example of demand-pull inflation). Thus there should be a limit to the FII inflow in the country.

\section{Figure 3:FIIs AND EXCHANGE RATE}

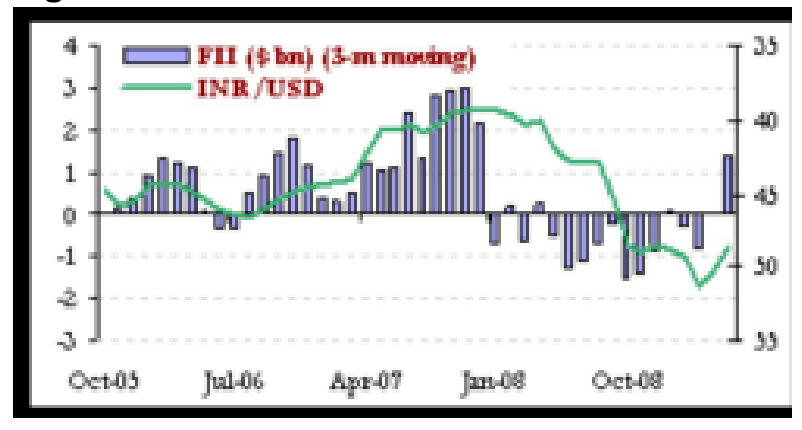

Forecasters were very bullish on India's growth story in the beginning of 2008 and were anticipating heavy FII inflows. But Flls actually pulled out $\$ 9.3$ billion from Indian markets in 2008. Due to these heavy capital outflows the INR tumbled to around 50-levels against the US\$ in December 2008. In 2008 dollar was weakening against the Euro and the pound. But that was not the case with the rupee, because capital flows were not good. The Reserve Bank of India sold a record $\$ 20.63$ billion foreign currency during October to check steep depreciation of the rupee. In another evidence, the rise of the rupee was the key economic development of 2007. FII investment saw the rupee close 2007 at 39.41 against the US dollar. Overseas investors bought a record $\$ 17.2$ billion of Indian shares in 2007, helping the rupee gain 12.3 per cent, the biggest annual gain since 1974. It touched 39.19 against the dollar on November 7, last year, the highest in nearly a decade. Recently on 17th May 2010, FII pulled out Rs. 1,224 crore from the stock markets though losses capped by Larsen \& Turbo's forecast beating quarterly earnings and recovery in European shares. The Fll outflow is considered temporary as foreign investors are likely to step up investments in strong emerging markets like India. The FII pullout was one of the reasons for the fall in the rupee as well. The rupee fell to its lowest level in nearly two and half months on 17th May 2010 as sovereign debt worries in the euro zone sent the single currency to four year lows. The Indian currency closed at 45.63 per dollar after hitting 45.77, its weakest since March 5, 2010.

Table 3: Sources of Accretion of FOREX Reserves since 1991 (US\$ Billion) Items

\begin{tabular}{|l|l|l|}
\hline & Items & $\mathbf{1 9 9 1 - 2 0 0 9}$ \\
\hline A & $\begin{array}{l}\text { Reserves } \\
\text { Outstanding as on end March 1991 }\end{array}$ & 5.8 \\
\hline B.I & Current Account Balance & -81.6 \\
\hline B.II & Capital Account (Net a to e) & 331.7 \\
\hline$a$ & Foreign Investment & 155.2 \\
& FDI & 75.8 \\
& FII & 51.6 \\
\hline$b$ & NRI Deposits & 34.1 \\
\hline$c$ & External Assistance & 18.6 \\
\hline$d$ & ECBs & 68.2 \\
\hline$e$ & Other Items in Capital Account & 55.6 \\
\hline B.III & Valuation Change & -4.0 \\
\hline & Total (A+BI+BII+BIII) & \\
\hline
\end{tabular}

Source: Reserve Bank of India 


\section{DETERMINANTS OF FII}

\section{International}

The classical capital asset pricing model (CAPM) predicts that, to maximize risk adjusted returns, investors should hold a diversified market portfolio of risky assets, irrespective of their country of residence. In practice, however, the proportion of foreign assets in investors' portfolios tends to be very small, and there is a home bias. There is evidence of the home bias decreasing over the years. The share of foreign shocks in the equity portfolio of US investors, for example, increased from an estimated $2 \%$ in the late 1980 s to $10 \%$ at the end of 1997 , but is still far short of the $52 \%$ of world stock market capitalization accounted for by non-US stocks.

A part of the home bias is because of barriers to international investment. The international CAPM predicts that individuals should hold equities from around the world in proportion to market capitalizations. This is predicated on the assumption that there are no barriers to international investment. In practice, such barriers do exist, but they are falling over time, including in India.

\section{India}

Using a monthly data-set for the period May 1993 to December 1999, found that the FII net inflows were not only correlated with the return in Indian equity market but was more likely the effects than the cause of the Indian equity market return. Flls did not appear to be at an informational is advantage compared to domestic investors in the Indian markets. Furthermore, the Asian crisis marked a regime shift. In the post-Asian crisis period, the return in the Indian equity market turned out to be the sole driver of the FII inflow, while for the pre-Asian crisis period other covariates reflecting return in other competing markets were also correlated with FII net inflow.

\section{LINKAGES WITH EXCHANGE RATE AND BALANCE OF PAYMENTS :}

Flls are attracted by returns calculated in foreign currency, say for example, in US dollars. Thus what is relevant is the return on their investment in rupee terms and the movement of the exchange rate of the rupee. A high rupee return on equities can be neutralizing, at least in part, by a depreciation of the rupee. For example, $15 \%$ rupee return on equities with a $7 \%$ depreciation of the rupee results in an effective dollar rate of return of about $8 \%$ only. Similarly, a relatively unattractive low rupee rate of return on equities can become attractive in dollar terms if the rupee appreciates vis-à-vis the dollar. Given everything else, FIl flows go up (down) when there are expectations of domestic currency appreciation (depreciation).

\section{BALANCE OF PAYMENTS}

India's BOP has strengthened almost continuously since the crisis of 1990-91, mainly because of a limited current account deficit more than compensated by a buoyant capital account. The external sector responded well to the liberalization of trade and current account, removal of quantitative restrictions and a steady reduction in customs duty rates from a peak rate of over 300 percent in 1990-91 to less than 30 percent in 2008-09.

The strength of the capital account, on the other hand, reflected the success of a cautious approach to liberalization with an opening up of the economy to FDI and FIIs, and restricting debt flows, Fll flows have made an important contribution to the Balance of Payments.

\section{Changes in the Balance of Payment system of recording}

The RBI, in conformity with the best international practices and as per the provisions of BoP Manual 5 of the IMF, made certain changes in the system of recording BoP flows. In the earlier system of recording of international transactions between residents and non-residents, trade credits or credits for financing imports by Indian residents extended by foreign suppliers up to 180 days were not covered explicitly and were subsumed under the head 'Other Capital' or errors and omissions. However, such credit beyond 180 days was recorded and reported. Usually very short-term credit less than 180 days gets rolled over within a year and as such they are recorded on a net basis only. However, using the internationally accepted methodology as recommended in BPM5, the RBI started recording these transactions for both 
Bop and external debt purposes. While in the case of BoP there was no change in the overall balance as other capital and errors and omissions were lower to the extent that short-term credits were higher, total stock of outstanding external debt went up.

\section{Investment Scenario}

Amid signs of improving liquidity, January 2010 has seen private equity investments in India double to US\$ 386 million, from US\$ 191 million in January 2009, according to the financial research body, VCEdge.

US-based private equity firm, New Silk Route Partners LLC (NSR), has picked up a little over 30 per cent stake in Chandigarh-based listed pharmaceutical company Nectar Life sciences Ltd for US\$ 54.5 million.

US-based investment management firm T Rowe Price Group (TRP), has bought a 26 per cent stake in UTI Asset Management Company (AMC) and UTI Trustee Company for US\$140.03 million.

During 2009, Kohlberg Kravis \& Roberts (KKR) PE firm's investment for increasing its stake in telecom software firm Aricent to 79 per cent for US\$ 255 million was the largest deal. Another remarkable deal was Goldman Sachs' US\$ 115 million investment in healthcare firm Max India for a 9.4 per cent stake.

Credit Suisse (Singapore) bought 1.12 per cent stake in Bharati Shipyard for US\$1.48 million.

Stocks that had more than 10 per cent of FIl stake (in BSE-500) in March went from 205 to 232 by end September. India bulls Real Estate, IVRCL Infrastructure, Educomp Solutions and United Spirits are a few stocks where Flls accumulated more shares despite already big holdings.

While foreign institutional investors (FIIs) purchased equities worth Rs7.36 trillion in gross and recorded a gross sale of Rs6.48 trillion in 2009, resulting in a net purchase of Rs87,987 crore at the end of the year.

FII inflow so far this year has broken the previous high of Rs80, 915 crore parked by foreign fund houses in domestic equities in 2007.
The Fll inflow of Rs87, 987 crore in 2009 is the high in the country in rupee terms in a single year.This comes a year after they pulled out over Rs41,216 crore, from the domestic bourses - a trend triggered with the collapse of global financial services icon Lehman Brothers in the middle of September 2008.

This selling trend continued till the first two months of 2009. However, with the sign of revival in global economies, the trend turned positive during March and overseas investors started betting big on the domestic bourses.

The trend of strong FII inflows to the tune of Rs31,000 crore (about $\$ 6.3$ billion) witnessed during April-June quarter of 2009 gained further during the September quarter and the period witnessed an infusion of hefty Rs34,313 crore.

In the December quarter, foreign fund houses made a net investment of about Rs 25,000 crore in the stock market, amid a period that witnessed the Dubai debt crisis.

Buoyed by FII inflow during 2009, the stock market barometer Sensex gained over $70 \%$, one of the best performers among leading global bourses, to $17,464.81$ points.

The FIl inflow in spot market increased to Rs83, 424 crore in 2009, as compared to withdrawals of Rs52, 987 crore in 2008 . However, foreign fund investment in debt market dropped to Rs4, 563 crore n 2009, from Rs 11, 772 crore in 2008, the survey added.

Funds flow from Flls have crossed the record Rs 97,900 crore mark this year. The net purchase of Rs $97,955.50$ crore ( $\$ 21.42$ billion) is the higher ever investment by overseas firms in any single year in India.

\section{Conclusion :}

From the above discussion it is clear that Flls has strong implications on Indian economy. In fact FIls are more than just money. It represents investor's sentiments. FII inflows and control have emerged as important policy issue in India. Among the Indian policymakers, Flls flows are believed to have a positive impact on the country's development. FII flows supplement and augment domestic savings and domestic investment without increasing the foreign 
debt of country. Added to this, FII inflows to the equity market increase stock prices, lower cost of equity capital and encourage the investment by Indian firms and lead to improvements in securities market design and corporate governance. But, recent upsurge in Flls inflows have generated many issues of concerns. The FII lead to appreciation of the currency, they lead to the exports industry becoming uncompetitive due to the appreciation of the rupee. But, recent evidence suggests that export is largely influenced by many other factors like cost and quality of product, not only by value of currency. India must learn to live with foreign capital

\section{REFERENCES :}

I Bahadur, Kanika (2007) Participatory Notes and Current Issues, The Hindu, March 10.

I Batra, A., (2003), The Dynamics of Foreign Portfolio Inflows and Equity Returns in India, Working Paper No. 109. ICRIER, New Delhi, India.

I Bose, Suchismita and Dipankar, Coondoo (2004) The Impact of FII Regulations in India, Money and Finance, July-December.

I Klein, W. Michael and Rosengren, Eric (1992), The Real Exchange Rate and Foreign Direct Investment in the United States: Relative Wealth vs Relative Wage Effects, Journal of International Economics, Vol. 36, No. 3-4, pp 373-390.

I Mishra, Neeraj (2008), FII Affecting Exchange Rates, Stock Markets, Inflation and Exports, accessed on http://neerajmishra.wordpress. com/2008/07/15/fii-affecting-exchange-ratesstock-markets-inflation-and-exports.
I Mody, Ashok, Mark P. Taylor and Jung Yeon Kim (2001), Modeling Fundamentals for Forecasting Capital Flows to Emerging Markets, International Journal of Finance and Economics, Vol. 6 No. 3, pp 201-216.

I Moin, Amir (2010), The Nuisance Formula and the FIl Hype, Business and Economy, Vol. 5, No. 13, pp 30-31.

I Rao, V. Chandra (2008), India's Present Policy Foreign Portfolio Investment, OPEC Review, Vol. 20, No. 4, pp 347-354.

I Srinivasan, p. and Bhat, Sham (2009), An Empirical Analysis of Flls and Stock Market Return in India, Foreign Trade Review, Vol. XLIV, No. 2, pp 60-79.

I Sumanjeet (2007), Appreciation of the Indian Currency: Implications for the Indian Economy, World Affairs: The Journal of International Issues, Vol. 1, No. 4.

I Sumanjeet (2009), Foreign Capital Flows into India: Compositions Regulations, Issues and Policy Options, Working Paper, No. 155, Murdoch University. Australia.

I Sumanjeet (2010), Global Financial Crisis and Indian Economy: A Journey from Recession to Recovery, Journal of International Economic Studies, No 24, (In Press)

I RBI (2007), Report on Foreign Exchange Reserves, Reserve Bank of India accessed on ht t p://rbidocs.rbi.org.in/rdocs/ PublicationReport/Pdfs/78800.pdf. 